\title{
The Historical Journey of Opera Translation in Turkey and its Perception by Contemporary Turkish Opera Performers
}

\section{Türkiye'de Opera Çevirisinin Tarihsel Yolculuğu ve Çağdaş Opera Sanatçılarının Çeviri Operaya Bakış Açısı}

\author{
Özlem Şahin Soy ${ }^{1}$ (1), Merve Şenol ${ }^{2}$ []
}

'Istanbul, Turkey

${ }^{2}$ Ufuk University, Vocational School, Applied English and Translation Program, Ankara, Turkey

ORCID: Ö.Ş.S. 0000-0003-1623-9027;

M.Ş. 0000-0003-0721-7635

Corresponding author:

Özlem Şahin Soy (PhD.),

Istanbul, Turkey

E-mail: ozlemsahinsoy@gmail.com

Submitted: 01.05 .2020

Accepted: 30.06 .2020

Citation: Sahin-Soy, O., \& Senol, M. (2020). The Historical Journey of Opera Translation in Turkey and its Perception by Contemporary Turkish Opera Performers. Istanbul Üniversitesi Çeviribilim Dergisi - Istanbul University Journal of Translation Studies, 13, 1-22

https://doi.org/10.26650/iujts.2020.13.0001

\begin{abstract}
Opera, evolving on the foundation of two art forms, theatre and music, is a multidisciplinary genre that has affected many countries and cultures profoundly over the centuries. Even though opera emerged and blossomed in Western societies in the early sixteenth century, it took four more centuries to pass so that opera could meet the Turkish audience. Translation from Western sources has been a substantial medium to Westernize and Europeanize the Ottoman Empire and Republican Turkey. The proclamation of Tanzimat was the beginning of transformation in the multicultural and multilingual Ottoman Empire to form a nation-state, and therefore the Westernization process started in all fields including literature and music. Opera was one of the new art forms that came into prominence apart from theatre and prose. Since the Republic gave much importance to polyphonic music and attempted to carry Turkish music into universal standards, works of art in the most paramount genre of music, the opera, were translated. Translations of operas were carried out by the Turkish composers of the time in order to achieve a singable and coherent translation in terms of prosody. In this context, this study aims to present both the historical journey of opera translation in Turkey and to introduce the remarks of some contemporary opera performers of Ankara State Opera and Ballet, who were interviewed so as to grasp their perception of translated opera.
\end{abstract}

Keywords: Opera Translation, Opera Performers, Singability, Westernization Process, Opera Translation in Turkey

\section{Öz}

Tiyatro ve müzik gibi iki sanat dalı temelinde ortaya çıkan opera yüzyıllar içerisinde birçok ülke ve ulusu derinlemesine etkileyen bir tür olmuştur. Erken on altıncı yüzyılda Batı ülkelerinde ortaya çıkmış ve gelişmiş olmasına rağmen operanın Türk seyircisiyle buluşması için dört yüz yıl daha geçmiştir. Osmanlı Devleti ve Türkiye Cumhuriyetini Batılılaştırma ve Avrupalılaştırma çabası içerisinde çeviri önemli bir araç olmuştur. Bir ulus-devlet kurma gayreti esnasında çok uluslu ve çok dilli Osmanlı Devletinde Tanzimat bir dönüşümün başlangıcı olmuştur ve bu sebeple Batılılaşma süreci edebiyat ve müzik alanları 
The Historical Journey of Opera Translation in Turkey and its Perception by Contemporary Turkish Opera...

dahil olmak üzere tüm alanlarda kendini göstermiştir. Cumhuriyet çok sesli müziğe önem verdiği ve Türk müziğini evrensel standartlara taşımaya çalıştığı için müziğin en eski ve en önemli alanı olan operada çeviriler yapılmıştır. Opera çevirileri, zamanın bestecileri tarafından yapılmış ve prozodiye uygun söylenebilir ve ahenk barındıran çeviriler ortaya konmaya çalışılmıştır. Bu bağlamda, bu çalışmanın amacı hem opera çevirisinin Türkiye'deki tarihsel serüvenini ortaya koymak hem de görüşülen Ankara Devlet Opera ve Balesinin çağdaş opera sanatçılarının çeviri opera hakkındaki düşüncelerini yansıtmaktır.

Anahtar kelimeler: Opera Çevirisi, Opera Sanatçıları, Batılılaşma Süreci, Söylenebilirlik, Türkiye'de Opera Çevirisi 


\section{Opera in the West}

With its most primitive traces dating back to the ancient Greek and Egyptian ages, opera -meaning theatre with music- could be found in the Dionysus theatre where Sophocles, Euripides and Aeschylus produced musical plays. Therefore, operatic hints of theatrical plays with musical instruments and songs could be felt in Ancient Greece; however, it was in the Middle Ages when music was used as part of religious ceremonies communicating the words of God. Under the governance of the Church, short religious plays were performed in churches throughout the Christian world along with a sacred musical composition called "the Mass", and thus, God's word was spread in a musical setting. Having been performed outside the church by traveler theatre companies, these religious plays with a musical and theatrical setting continued to fulfill their sacred mission of communicating the words of God and did not lose popularity until the end of the sixteenth century.

Having triggered new pursuits and developments in religion, science, state affairs, law, and art forms, the Renaissance brought about change in the perception of music and theatre as well. Along with improvements in these fields, opera encountered swift developments with the effects of the Enlightenment period and started to be regarded as the composition of theatre, music, poetry, and plastic arts. Italy dominated the interest given towards opera and Italian composer and choirmaster Claudio Monteverdi, the pioneer in the development of opera, gave rise to polyphonic and melodic supremacy in opera. Although interest towards opera was paramount in Italy in the sixteenth and seventeenth centuries, other European countries such as Spain, France, Germany and England did not share the same level of enthusiasm and opera remained under the leadership of Italy for many centuries. In the course of time, the art of opera evolved and enriched with its new genres. The eighteenth century saw an interaction between Italy, France, Germany and England, which led to similar libretti and operas being produced. This interaction between Italy and France paved the way for a shift in the activities of opera from Italy to Paris, and "although Italian remained the main operatic language until the nineteenth century, Italian opera began to compete with French opera sung in French characterized by simpler melodies..." (Desblache, 2007: 159). The greatest progress in opera was observed in the nineteenth century as a result of a reaction to the Age of Enlightenment of the eighteenth century. With the impact of the Romantic Era, which most strongly affected music, literature and arts, every country began developing their own sense of music and composed operas conveying every country's national entity and color. In the twentieth century, the period when the world stage experienced two world wars and faced their brutal consequences, opera was shaped more nationally and until the end of the 1950s, a national score could be observed in the compositions of composers of the time, particularly in the aftermath of the First World War. 


\section{Opera and the Ottoman Empire}

Meanwhile in the second half of the eighteenth century, under the ruling of Selim III, who had undertaken the Westernization process of the Ottoman Empire with the ardor created by the intellectual and political revision of the French Revolution, the Ottoman Empire discovered the word 'opera' through the itineraries written by ambassadors sent to cities like Paris and Vienna where they had experienced the wondrous art of opera. However, it wasn't until the nineteenth century that opera could be fully integrated with the Ottoman literary and art system. As stated by Şahin Soy and Şenol Özdemir, "with the proclamation of Tanzimat in the nineteenth century, the Ottoman literary polysystem entered a new era. The innovations introduced with Tanzimat changed many customs in the literary polysystem, starting with Divan literature which, at that point, wasn't able to produce works of art in necessary genres such as drama and novel" (Şahin Soy and Şenol Özdemir, 2015; 199). Many universally critical works, mostly from French and Italian, were translated and introduced into the Ottoman literary polysystem, and the educated élites took on the task of educating the public through these translations. During this period, "the hierarchies operating in the Ottoman literary polysystem, which prior to the Tanzimat period had been closed to contact with European literatures, started to change, enabling translated literature to move from the periphery towards the centre of the polysystem..." (Berk, 2004: 49). Prior to Tanzimat, the Ottoman literature was in close contact, not with the Western, but the Eastern literatures of Iranian and Arabic origin, whose literary understanding could not satisfy the needs and expectations of the young generation of the Ottoman Empire. The Westernization process, whose steps were taken by Selim III, could only be realized through translating the most important works of European literature and in the end, producing national works of art which had European imagery, understanding, and taste.

Opera was one of the most important works of European art that the Ottoman literary and art polysystem lacked. As put forth by Şahin Soy and Şenol Özdemir, 'the monophonic nature of the Ottoman musical conception had to pass onto the internationally adopted polyphonic nature and new and contemporary techniques had to be employed in order to communicate with the West in terms of music and art" (Şahin Soy and Şenol Özdemir, 2015; 201). Italian opera was regarded as the most paramount example for the practices taken under renovating Ottoman music and works of Italian composers were staged in multicultural cities of the Ottoman Empire, namely Istanbul and Izmir, where opera houses and theatres were built so that opera performances could be staged. However, due to the political recession and turmoil of the Ottoman Empire after the year 1885, studies towards opera and polyphonic music had to be suspended until the proclamation of the Republic in 1923.

\section{Opera Convention in the Republic of Turkey}

With the proclamation of the Republic, the main goal was set of carrying the young nation to the level of civilized societies as of the West. To that end, translation played a pivotal role in 
forming a new nation with Western political, ideological and scientific cognizance. Works in science, ideology, politics, culture, and literature of contemporary Western civilizations were examined and translated, setting the stage for producing national ideologies, literary works, and cultural legacies. Since education and educational institutions lacked importance in the period of Tanzimat in the Ottoman Empire, a sustainable musical improvement could not be carried out. Therefore, Mustafa Kemal Atatürk designated the state music policy as "kneading a new music by grounding on Turkish folk music and using polyphonic techniques and methods which were developed in the West" (Directorate General of State Opera and Ballet: p.9). Hence, in the early years of the Republic, talented young students were sent abroad to study music and convey their knowledge. The educational process of these talented students was not short and when they came back from Europe having completed their education, it was the 1930s. These students who were educated abroad immediately started working in Musiki Muallim Mektebi in Ankara and Darül Elhan in Istanbul so as to train others to become opera composers and performers. Not only did the regime of the Republic send students abroad to study music and particularly opera, but also brought experienced foreign musicians to Ankara and Istanbul in order to carry Turkish music into universal standards, form a nationally accepted musical individuality, and produce works of art in the most paramount genre of music, the opera. Translations of Western compositions like plays and operas preoccupied the early years of the young Republic and with the establishment of the Konservatuar which was formerly called Darül Elhan (House of Music) where more significance started to be given to Western music. According to Şahin Soy and Şenol Özdemir, "Carl Ebert's studies in Ankara State Conservatory and the students' effort to try staging universally accepted operas in Turkish libretti led to the staging of W. A. Mozart's one-act opera 'Bastien and Bastienne' in Turkish accompanied by the Presidential Symphony Orchestra” (Şahin Soy and Şenol Özdemir, 2015; 201). Berk also states that opera performances in the 1940s started with extracts from Tosca and Madam Butterfly by Giacomo Puccini, followed by Fidelio by Ludwig van Beethoven, The Bartered Bride by Dedrich Smetana and Le Nozze di Figaro by Wolfgang Amadeus Mozart (Berk, 2006: 11). Translation of all foreign operas in the early years of the Republic was carried out in a way that the public could understand the words easily alongside music so that the desire for opera would continue to exist.

The above-mentioned and many more operatic plays were translated, performed and staged in Turkish in order to first make the ordinary public of the young Republic familiar with opera, which could not be achieved in the days of the Ottoman Empire due to the lack of interest of the ruling class towards the peasantry. Secondly, as the most important aspect of the Westernization process was also to form a national literature affected by Western imagery, culture and music, these translations of famous Western operas would lead Turkish composers to be affected by these translations and create operas in Turkish. As stated by Komşuoğlu and Turan, "three operas by Turkish composers were performed in the theatre of the Ankara Halkevi (People's 
House). The first performance was the Özsoy Opera composed by Adnan Saygun. [...... This opera was evaluated as the core of the Turkish opera and a national and original composition which was adapted to universal musical norms" (Komşuoğlu and Turan, 2007: 20)

\section{A Selection of Translated Operas into Turkish}

In order to clarify the importance of translated operas in Turkey, a selection of translated opera libretti from the 1940s until the 2000s are given in tables and commented on. In order to depict the changes in the languages of the performed plays and the translators, the years of the 1940s, 1970s and 2000s have been modeled. The names and the professions of the translators, the original names and the languages of the opera plays and the seasons when the plays were performed are put forward.

\begin{tabular}{|c|c|c|c|}
\hline Name of the Opera & Season & City & Turkish Version By \\
\hline Madame Butterfly & 1941 & Ankara & Celalettin EMREM \\
\hline Madame Butterfly & 1941 & Ankara & Cevad Memduh ALTAR \\
\hline Madame Butterfly & 1941 & Ankara & Hasan Ferid ALNAR \\
\hline Madame Butterfly & 1941 & Ankara & Necil Kazım AKSES \\
\hline L. V. Beethoven & 1942 & Ankara & Cevad Memduh ALTAR \\
\hline Fidelio & 1942 & Ankara & Ulvi Cemal ERKIN \\
\hline Fidelio & 1942 & Ankara & Necil Kazım AKSES \\
\hline L. V. Beethoven & 1942 & Ankara & Nurullah Şevket TAŞKIRAN \\
\hline Prodanána Nevěsta (The Bartered Bride) & 1943 & Ankara & Halil Bedi YÖNETKEN \\
\hline $\begin{array}{l}\text { Performances of Izmir Fair - King } \\
\text { Oedipus/Antigone/La Locondiera/La } \\
\text { Bourgeois Gentilhomme }\end{array}$ & 1944 & İzmir & Ali Süha DELİLBAŞI \\
\hline $\begin{array}{l}\text { Performances of Izmir Fair - King } \\
\text { Oedipus/Antigone/La Locondiera/ } \\
\text { LaBourgeoisGentilhomme }\end{array}$ & 1944 & İzmir & Bedrettin TUNCEL \\
\hline $\begin{array}{l}\text { Performances of Izmir Fair - King } \\
\text { Oedipus/Antigone/La Locondiera/ } \\
\text { LaBourgeoisGentilhomme }\end{array}$ & 1944 & İzmir & Nüzhet Haşim SİNANOĞLU \\
\hline $\begin{array}{l}\text { Performances of Izmir Fair - King } \\
\text { Oedipus/Antigone/La Locondiera/ } \\
\text { LaBourgeoisGentilhomme }\end{array}$ & 1944 & İzmir & S. ALI \\
\hline Madame Butterfly & 1945 & Ankara & Celalettin EMREM \\
\hline Madame Butterfly & 1945 & Ankara & Cevad Memduh ALTAR \\
\hline La Boheme & 1945 & Ankara & Halil Bedi YÖNETKEN \\
\hline Madame Butterfly & 1945 & Ankara & Hasan Ferid ALNAR \\
\hline Fidelio & 1945 & Ankara & Necil Kazım AKSES \\
\hline
\end{tabular}




\begin{tabular}{|l|c|c|c|}
\hline Madame Butterfly & 1945 & Ankara & Necil Kazım AKSES \\
\hline La Boheme & 1945 & Ankara & Nurullah Şevket TAŞKIRAN \\
\hline La Boheme & 1945 & Ankara & S. ALI \\
\hline Fidelio & 1945 & Ankara & Ulvi Cemal ERKİN \\
\hline La Boheme & 1945 & Ankara & Ulvi Cemal ERKİN \\
\hline Carmen & 1948 & Ankara & Necil Kazım AKSES \\
\hline Carmen & 1948 & Ankara & Ulvi Cemal ERKİN \\
\hline
\end{tabular}

As can be seen above, for the season of 1941 Celalettin Emrem together with Necil Kazım Akses, Hasan Ferid Alnar, and Cevad Memduh Altar performed a prosodic translation of the Italian libretto of the opera "Madame Butterfly". It was understandable to have a musicologist, art historian, and the author Altar, the contemporary Turkish music composer Alnar, the founder of contemporary Turkish music and the 1958 director of the State Opera and Ballet Akses, and Turkish musician Emrem to translate the libretto by respecting the prosody of the Turkish language. "Madame Butterfly" was also later performed with that translated libretto in the season of 1945. In the season of 1942, "Fidelio" and "L.V Beethoven" were performed. The translation of German libretto of Fidelio was performed by the contemporary Turkish music composers Ulvi Cemal Erkin and Necil Kazım Akses together and the opera play was also staged in the season of 1945 . In the season of 1944, much importance was given to the performances in Izmir Fair. Opera plays including "King Oedipus", "Antigone", "La Locondiera", "La Bourgeois Gentilhomme" were staged and their translations were performed by playwright Ali Süha Delilbaşı, the founder of the Theatre Institute of the Faculty of Letters, Bedrettin Tuncel, and consul general Nüzhet Haşim Sinanoğlu, who died in 1941. "King Oedipus" or "Oedipus Rex" is a tragic Latin opera oratorio by Igor Stravinsky. "Antigone" was written in German by Carl Orff. "La Bourgeois Gentilhomme" was written in French by Molière and" La Locondiera" was written in Italian by Carlo Goldoni. The season of 1945 included the opera plays Madame Butterfly and Fidelio, whose translators have already been mentioned above. However, "La Boheme" was also performed in 1945 alongside with "Madame Butterfly" and "Fidelio". Its prosodic translation was performed by musicologist Halil Bedi Yönetken, flutist and opera performer Nurullah Şevket Taşkıran and S. Ali. In the season of 1948, "Carmen", which is an opera in four acts by the French composer Georges Bizet, was performed on the stage. Its prosodic translation was also performed by Akses and Erkin.

In short, after the proclamation of the Republic, Turkish music went through a change and young contemporary composers translated libretti from Italian, German and French. The prosodic translations and the teamwork behind those translations show that for a translation to meet the needs of both the music and the language, translators experienced in music are needed. Since the national policy of that time was to educate the people of the newly formed nation, the operas were staged in Turkish versions whose translations were carried out by giving importance to the musico-verbal setting of the original and Turkish languages. 


\begin{tabular}{|c|c|c|c|}
\hline Name of the Opera & Season & City & Turkish Version By \\
\hline $\begin{array}{l}\text { Cavalleria Rusticana/ Pagliacci/ Der } \\
\text { Garf von Luxemburg }\end{array}$ & $1970-1971$ & Ankara & $\begin{array}{l}\text { Fuat TURKAY- Nurullah Şevket } \\
\text { TAŞKIRAN- Ulvi Cemal ERKİN }\end{array}$ \\
\hline La Boheme & $1970-1971$ & Ankara & $\begin{array}{c}\text { Halil Bedi YÖNETKEN- Nurullah } \\
\text { Şevket TAŞKIRAN- Ulvi Cemal } \\
\text { ERKİN }\end{array}$ \\
\hline Faust/ Turandot & $1970-1971$ & Ankara & $\begin{array}{c}\text { Hasan Ferid ALNAR-Necil Kazım } \\
\text { AKSES- Ulvi Cemal ERKINN }\end{array}$ \\
\hline Madame Butterfly & 1971-1972 & Ankara & $\begin{array}{c}\text { Celalettin EMREM- Cevad Memduh } \\
\text { ALTAR-Hasan Ferid ALNAR-Necil } \\
\text { Kazım AKSES }\end{array}$ \\
\hline Rigoletto & 1971-1972 & Ankara & Hasan Ferid ALNAR \\
\hline La Traviata & 1971-1972 & Ankara & $\begin{array}{c}\text { Hasan Ferid ALNAR- Saadet Alp } \\
\text { IKESUS ALTAN }\end{array}$ \\
\hline The Consul & $1971-1972$ & Ankara & Necil Kazım AKSES \\
\hline Carmen & 1971-1972 & Ankara & $\begin{array}{c}\text { Necil Kazım AKSES- Ulvi Cemal } \\
\text { ERKİN }\end{array}$ \\
\hline The Barber of Seville & 1971-1972 & Ankara & $\begin{array}{c}\text { Necil Kazım AKSES-Ulvi Cemal } \\
\text { ERKİN }\end{array}$ \\
\hline Gianni Schicchi/ Allamistakeo & $1972-1973$ & Ankara & $\begin{array}{l}\text { Düriye KÖPRÜLÜ-Hüsamettin } \\
\text { ÜNDER- Nazım ENGİN AR- } \\
\text { Sabahattin KALENDER }\end{array}$ \\
\hline Il Tabarro/ Amelia Goes To the Ball & $1972-1973$ & Ankara & $\begin{array}{c}\text { Hüsamettin ÜNDER-Nevit } \\
\text { KODALLI-Ulvi Cemal ERKİN-Halil } \\
\text { Bedi YÖNETKEN }\end{array}$ \\
\hline Aida & $1972-1973$ & Ankara & $\begin{array}{c}\text { Necil Kazım AKSES- Ulvi Cemal } \\
\text { ERKİN }\end{array}$ \\
\hline Çardaş Fürstin (Çardaş Prensesi) & $1972-1973$ & Ankara & Aydın GÜN \\
\hline Cavalleria Rusticana/ Pagliacci & $1973-1974$ & Ankara & $\begin{array}{c}\text { Cevad Memduh ALTAR-Nurullah } \\
\text { Şevket TAŞKIRAN- Ulvi Cemal } \\
\text { ERKIN- Fuat TURKAY }\end{array}$ \\
\hline Madame Butterfly & 1973-1974 & Ankara & $\begin{array}{c}\text { Cevad Memduh ALTAR-Hasan Ferid } \\
\text { ALNAR-Necik Kazım AKSES- } \\
\text { Celalettin EMREM }\end{array}$ \\
\hline La Traviata & 1973-1974 & Ankara & $\begin{array}{c}\text { Hasan Ferid ALNAR- Saadet ALP } \\
\text { İKESUS ALTAN }\end{array}$ \\
\hline Rigoletto & 1973-1974 & Ankara & Hasan Ferid ALNAR \\
\hline Tosca & 1973-1974 & Ankara & Hasan Ferid ALNAR \\
\hline Don Pasquale & $1973-1974$ & Ankara & Nazım ENGIN AR \\
\hline Mavra Oluşum- Le Rossignol (Bülbül) & $1973-1974$ & Ankara & $\begin{array}{c}\text { Necdet AYDIN- Nevit KODALLI- } \\
\text { Yalçın DAVRAN }\end{array}$ \\
\hline Othello & 1973-1974 & Ankara & $\begin{array}{c}\text { Necil Kazım AKSES- Ulvi Cemal } \\
\text { ERKIN }\end{array}$ \\
\hline
\end{tabular}




\begin{tabular}{|c|c|c|c|}
\hline Andrea Chenier & $1974-1975$ & Ankara & $\begin{array}{l}\text { A. CASTEGNETTI- Saadet ALP } \\
\text { IKESUS ALTAN }\end{array}$ \\
\hline La Sonnambula & $1974-1975$ & Ankara & Fuat TURKAY- Ulvi Cemal ERKİN \\
\hline $\begin{array}{l}\text { Prodanána Nevěsta (The Bartered } \\
\text { Bride) }\end{array}$ & $1974-1975$ & Ankara & $\begin{array}{c}\text { Halil Bedi YÖNETKEN- Nurullah } \\
\text { Şevket TAŞKIRAN }\end{array}$ \\
\hline La Boheme & $1974-1975$ & Ankara & $\begin{array}{c}\text { Halil Bedi YÖNETKEN- Nurullah } \\
\text { Şevket TAŞKIRAN- Ulvi Cemal } \\
\text { ERKİN }\end{array}$ \\
\hline Adriana Ledcouvreur & $1974-1975$ & Ankara & $\begin{array}{l}\text { Hüsamettin ÜNDER- Sabahattin } \\
\text { KALENDER- Düriye KÖPRÜLÜ }\end{array}$ \\
\hline $\begin{array}{l}\text { Il Seraglio (The Abduction from the } \\
\text { Seraglio) }\end{array}$ & $1974-1975$ & Ankara & Nihat KIZILTAN \\
\hline Çardaş Fürstin (Çardaş Prensesi) & $1975-1976$ & Ankara & Aydın GÜN \\
\hline Oh du Lieber Augustin & 1975-1976 & Ankara & Edip ARMAN- Gültekin ORANSAY \\
\hline Romeo and Juliet & $1975-1976$ & Ankara & Nazım ENGIN AR \\
\hline Il Trovatore & 1975-1976 & Ankara & Nazım ENGİN AR \\
\hline The Medium (Medyum) & 1975-1976 & Ankara & Saadet ALP İKESUS ALTAN \\
\hline $\begin{array}{l}\text { Il Campanello/ La Cambiale/ Di } \\
\text { Matrimonio }\end{array}$ & $1975-1976$ & Ankara & Saadet ALP IKESUS ALTAN \\
\hline Madame Butterfly & $1976-1977$ & Ankara & $\begin{array}{c}\text { Cevad Memduh ALTAR- Hasan Ferid } \\
\text { ALNAR- Necil Kazım AKSES- Ulvi } \\
\text { Cemal ERKIN }\end{array}$ \\
\hline Cavalleria Rusticana/ Pagliacci & $1976-1977$ & Ankara & $\begin{array}{c}\text { Cevad Memduh ALTAR- Fuat } \\
\text { TURKAY }\end{array}$ \\
\hline Un Ballo in Maschera (A Masked Ball) & 1976-1977 & Ankara & Hasan Ferid ALNAR \\
\hline Der Zigeunerbaron (The Gypsy Baron) & $1976-1977$ & Ankara & Sabahattin KALENDER- Saip SAN \\
\hline Cavalleria Rusticana/ Pagliacci & $1976-1977$ & Ankara & Ulvi Cemal ERKİN \\
\hline Fledermaus (Yarasa) & $1977-1978$ & Ankara & Hakkı Şinasi ÖZEL-Aydın GÜN \\
\hline La Traviata & $1977-1978$ & Ankara & $\begin{array}{c}\text { Hasan Ferid ALNAR- Saadet ALP } \\
\text { IKESUS ALTAN }\end{array}$ \\
\hline Rigoletto & $1977-1978$ & Ankara & Hasan Ferid ALNAR \\
\hline Halka (Helen) & $1977-1978$ & Ankara & $\begin{array}{c}\text { Hüsamettin ÜNDER- Sabahattin } \\
\text { KALENDER }\end{array}$ \\
\hline The Barber of Seville & $1977-1978$ & Ankara & $\begin{array}{c}\text { Necil Kazım AKSES-Ulvi Cemal } \\
\text { ERKIN }\end{array}$ \\
\hline The Marriage of Figaro & $1978-1979$ & Ankara & $\begin{array}{c}\text { Hasan Ferid ALNAR-Necil Kazım } \\
\text { AKSES }\end{array}$ \\
\hline
\end{tabular}

Table 2 shows that many plays from "La Boheme" to "Don Giovanni" were staged between the years 1970 and 1979. The opera "Madam Butterfly" was put on stage in the years between 1970-1979 with its prosodic translation done by Emrem, Altar, Akses and Alnar years ago. The others are unfortunately unknown. However, it is a fact that the translations done by Halil Bedi Yönetken, Nurullah Şevket Taşkıran, Hasan Ferid Alnar, Necil Kazım Akses, Ulvi 
Cemal Erkin, and Cevad Memduh Altar were prosodic translations, since they were composers, musicologists or art historians of their time, which meant that the plays were staged in their Turkish versions. Fuat Turkay and Ulvi Cemal Erkin translated the libretto of "Cavalleria Rusticana" together. The translations of Saadet Alp İkesus Altan, who was both an opera performer and translator, are also believed to be prosodic translations of the opera libretti. Another translator whose translations are mentioned in the table above is Düriye Köprülü, who was one of the women composers of Turkey in the early years of the Turkish Republic. Therefore, it can also be interpreted that her translations were also prosodic translations of the original libretti. When Cüneyt Gökçer was the General Director of the State Opera and Ballet, the above-mentioned translator Hüsamettin Ünder was the Vice-General Director of Music and Artistic Director and as can be seen, there are translations of opera libretti form Italian to Turkish by him. Sabahattin Kalender was also a Turkish composer and conductor, whose translations can be found in the table above. Another translator mentioned above is Aydın Gün who was an opera performer and a stage manager. There are two translations of libretti by him staged in the years between 1970 and 1979, which are "Çardaş Fürstin" and "Fledermaus".

Even though the years of the translations are unknown, it is evident that opera performers, musicologists or composers of that time translated the opera libretti taking the prosody of the Turkish language into consideration and thus, the operas were staged with their prosodic translations. Since 1983 was the year surtitles started to be used in operas for the first time, it can also be commented that the translations mentioned in both of the tables above were carried out for staging the operas in Turkish.

\begin{tabular}{|l|c|c|c|}
\hline \multicolumn{7}{|l|}{ Table 3. Works translated into Turkish in the 2000s } \\
\hline Name of the Opera & Season & City & Turkish Version By \\
\hline Don Giovanii & $2011-2012$ & Ankara & Ali TAYGUN \\
\hline Der Zigeunerbaron & $2011-2012$ & Izmir & Aydın GÜN \\
\hline Rusalka & $2011-2012$ & Ankara & Edip ARMAN \\
\hline Cosi Fan Tutte & $2011-2012$ & Mersin & Ercan YENAL \\
\hline $\begin{array}{l}\text { Prodanána Nevěsta (The Bartered } \\
\text { Bride) }\end{array}$ & $2011-2012$ & Antalya & Halil Bedi YÖNETKEN \\
\hline $\begin{array}{l}\text { Prodanána Nevĕsta (The Bartered } \\
\text { Bride) }\end{array}$ & $2011-2012$ & Antalya & Nurullah Şevket TAŞKIRAN \\
\hline Cosi Fan Tutte & $2011-2012$ & Mersin & Suna ERTEKİN \\
\hline Don Giovanni & $2011-2012$ & Ankara & Yekta KARA \\
\hline Turandot & $2011-2012$ & Izmir & Yiğit GÜNSOY \\
\hline Don Pasquale & $2011-2012$ & Mersin & Nazım ENGIN AR \\
\hline Lale Çlgınlı̆ı̆ & $2012-2013$ & Antalya & Baturalp BİLGILİ \\
\hline Lo Speziale (The Apothecary) & $2012-2013$ & Ankara & Edip ARMAN \\
\hline
\end{tabular}




\begin{tabular}{|l|c|c|c|}
\hline $\begin{array}{l}\text { Prodanána Nevěsta (The Bartered } \\
\text { Bride) }\end{array}$ & $2012-2013$ & Mersin & Halil Bedi YÖNETKEN \\
\hline Carmen & $2012-2013$ & Mersin & Necil Kazım AKSES \\
\hline $\begin{array}{l}\text { Prodanána Nevěsta (The Bartered } \\
\text { Bride) }\end{array}$ & $2012-2013$ & Mersin & Nurullah Şevket TAŞKIRAN \\
\hline Carmen & $2012-2013$ & Mersin & Ulvi Cemal ERKİN \\
\hline
\end{tabular}

The years between 2000 and 2013 were very fruitful for opera and many operas were staged not only in Ankara but also in Mersin, Istanbul, Izmir, and Antalya. However, as using surtitles was widely used during those years, accurate information could not be obtained from the General Directorate of the State Opera and Ballet. Since only information regarding the seasons 2011-2012, 2012-2013 and 2013-2014 could be obtained from the General Directorate of the State Opera and Ballet, Table 3 focuses on these seasons.

In light of that information, it can be said that in the season of 2011-2012 "Tosca", "Macbeth", "Tannhäuser", "Don Giovanni", "Il Seraglio", were staged in their original languages, Italian and French, with Turkish surtitles and the operas "Rusalka" and "La Cambiale di Matrimonio" were staged with Turkish libretti in Ankara. In Istanbul, all opera plays were staged in their original languages. In Izmir, "Cosi Fan Tutte", "Turandot", "Agrippina", and "Iphigénie en Tauride" were staged in their original languages with Turkish surtitles; however, "Il Seraglio", "Der Zigeunerbaron" and "Arşın Mal Alan" were staged with Turkish libretti. In Mersin, "Abu Hassan" and "Don Pasquale" were performed in Turkish, the others in their original languages. In Antalya, "The Bartered Bride" was staged in Turkish. In Samsun, "La Boheme" and "Çardaş Fürstin" were also staged with Turkish libretti.

In the season of 2012-2013, "Lo Speziale (The Apothecary)" and "La Cambiale di Matrimonio" were staged with Turkish libretti; however, "Don Giovanni", "Macbeth", "Rigoletto", "Il Seraglio" and "Tosca" were performed in their original languages with Turkish surtitles in Ankara. "Hasanaganica”, “Opera Müdürü” by Mozart, "Die Lustige Witwe" were staged in Turkish, the others in their original libretti with Turkish surtitles. In İzmir, "Il Seraglio", "Arşın Mal Alan" and "Der Zigeunerbaron" were staged in Turkish. "La Sonnambula", "Othello", and "Agrippina" were staged with their original libretti. In Mersin, "Carmen", "Madame Butterfly", and "Cosi Fan Tutte" were staged in their original languages with Turkish surtitles whereas "Don Pasquale" and "The Bartered Bride" were performed in Turkish. In Antalya, only "The Bartered Bride" was staged in Turkish, the other operas were staged in their original languages with Turkish surtitles. In Samsun, "La Boheme" and "Çardaş Fürstin" were staged in Turkish, whereas "Madame Butterfly" was staged in its original language with Turkish surtitles.

In the season of 2013-2014, out of ten operas, three of them, "Fledermaus", "Lo Speziale (The Apothecary)" and "Arşın Mal Alan" were staged in Turkish in Ankara. In Istanbul, out of 12 operas only one of them was played in Turkish, which was Mozart's opera "Opera 
Müdürü’. In Izmir, Mersin and Antalya, all operas were played in their original languages with Turkish surtitles that season, of course except for the operas written originally in Turkish. In Samsun, out of four operas, two of them were staged with Turkish libretti called "Birjan and Sara" and "Die Lustige Witwe".

In line with this information, it can be said that operas are not only staged in their original languages with Turkish surtitles but also in Turkish translated versions. Some translations of these operas, such as the ones of "The Bartered Bride" and "Fledermaus", were carried out years ago by the musicologists and composers who were mentioned earlier. Some adaptations to the modern Turkish language are naturally implemented but it is clear that importance is given to the previously done prosodic translations of those operas. Since every season, some operas are staged in Turkish libretti alongside the original operas, it can be derived that translation still maintains a central position in the Turkish literary polysystem for enabling more operas to be introduced to the Turkish public and to be produced by Turkish composers in Turkish via the help of translated libretti. It is evident that operas will be staged in both their original and Turkish forms in the future to make the literary polysystem benefit from translations and to educate the public of Turkey.

As the historical review above reveals, libretto translation is a raw area, which requires attention due to its importance as a bridge in the cultural reformation of Turkey. This study necessitates a multi-disciplinary approach and survey in the field to understand the opinions of the performers and their observations about the audience reactions towards the translated opera libretto. To this end, we have organized a research framework in which we formed eight research questions and had interviews with opera performers of the Ankara State Opera and Ballet in Turkey. Thus, the perception of opera in the eyes of opera performers has been assessed through a semi-structured interview technique, which also targeted to understand either the acceptance or the rejection of performing opera in the Turkish language. One of the purposes of this study is to present if translation is a burden for the performers that detracts the art from the audience or whether translations are done in a performable and singable way as necessitated by the prosody and phonetic structure of the Turkish language. In light of the above-mentioned information, this research also aims to put forward an adequate, contemporary, performable and applicable approach to translating opera libretti in order not to face word-by-word translations where meaning gets completely lost. The research also gives opinion to the reader about the transference of a Western art form into a culture that bridges East and West through transference in a language from a different linguistic family. Therefore, the answers of the interviewees, who were randomly selected opera performers, can be handled from various aspects.

The basic research question in this study, whose answer was sought, is "what opera artists think about the development of opera in Turkey, the translation of opera into the target language and its performance in the target language". In this respect, this part of the study is in "survey design" (Creswell, 2003: 175). 
The research population is composed of the opera performers who were working as tenured in Ankara State Opera and Ballet with many years of experience. The sample group, on the other hand, is composed of five randomly chosen opera performers working in the Ankara State Opera and Ballet. The tone color of all the performers is soprano and all of them performed operas both in the original and in translated versions. These translated versions were Turkish versions of the operatic plays.

\section{Interview Questions of the Research}

1. What do you think about the perception of opera in Turkey? Can we talk about a difference in the perception of opera from the past until today?

2. Have you ever sung a libretto translated into Turkish? Do you think that a libretto can be sung when it is translated into Turkish?

3. Should an opera performer believe in the words he/she is singing?

4. As an opera performer, in which language would you prefer singing the opera?

5. Do you think that performing opera in the target language will provide benefit in both a material and moral way?

6. Will the translation of opera libretto affect the performance or staging of the opera?

7. How should the language of the translated libretto be? Will a translation adapted to modern Turkish satisfy you?

8. What do you think is the expectation of an average Turkish audience from the opera? Should an opera address to the ears or the eyes?

\section{Findings and Results}

In this part, the findings involving the answers to the survey questions and the results take place. The findings are given in the order of the answers given to the questions and in the order of the interviewees replying to the questions respectively. The results include not only the findings of the research questions but also the interpretation of the data along with the theories and information provided by the scholars of the field. Findings and results are put forward by blending the collected data.

According to the answers given to the first question by all the interviewees, opera should be in the socio-cultural policies of the government. It is the view of three of the interviewees that opera education has to be given to children at a very early age and for that duty to fall onto the families, schools and most importantly, the Ministries. This education can be given by recording the singable translated versions of the most popular operas and having children listen to some parts of them in music lessons. The common view of the opera performers is that opera can only be understood and appreciated by people if it is given place in the policies of the government. 
The change in the language form of the operas is believed to be the result of policies adopted. In the past, approximately 25-30 years ago, performers sang the operas in translated Turkish versions so that the public could perceive the opera easily. However, in recent years, this habit has changed and they have been singing the operas in their original language. Nevertheless, there can be one other possible reason for the change in the language of the operas, which are performed. From the statements by all the interviewees for the second question, it can be deduced that in recent years, translations of the opera libretti have not been favored by even the opera performers themselves. Their strong belief is that the original words were composed to fit the pre-existing music and the translations they have met, which are regarded as bad by the performers, have probably increased the prejudice towards the translations of opera libretti and performances in translated versions. This issue was also stated by the scholars of the field, including Peter Low and Ronnie Apter. Low's view supported that "highlighted words should be translated at the same location because the composer is giving them special importance" (Low, 2005: 193). As important as it is to convey the sense and the meaning of the libretto in the best possible way, scholars also admit that equivalence is not desirable in libretti translation. However, for a singable translation to happen, Low points out that "loyalty and focusing narrowly on the characteristics of the original libretto would be unwise" (Low, 2005: 185). So, in order to make a good translation, the translator actually should not focus on the characteristics of the original libretto but be aware of the sounds of the language the translation is being made into. Therefore, Apter and Herman state "as no two languages have exactly the same sounds attempts to reproduce sounds are largely exercises in futility and selfdeception" (Apter and Herman, 1995: 27). Then, it can be derived that the opera performers strive for the harmony, and the melody within the words and such melodic words should be chosen while translating the original libretti.

In light of the answers given to the third question, it is understood that the performers have to believe in the words they are singing. This applies to both the original words and the translated ones. In the original form, it is clear that the performers study the language in which they are going to sing in order to achieve the best stress and pronunciation in that foreign language. In the translated versions, as the translations they have all mentioned were insufficient translations, it can be derived that the performers did not believe in the words they were singing. In order for the translated text to be singable, words that can be believed in should be used. Singability, here, does not only mean 'easy to sing' but for words to be accepted and therefore singable by the singers themselves. As Low pointed out "a singable translation of songs must facilitate oral performance" (Low, 2003: 89). Oral performance can only be facilitated if the right words are chosen for the singers. As the librettist Eric Crozier pointed out "capture the spirit of the text, but forget the source words" (cited in Orero and Matamala, 2007: 263-264). It can be concluded that, even in the translated versions, if the spirit of the libretto is captured then the words can be believed by the performers and the feelings can be conveyed. 
As far as the answers given to the fourth question, it is evident that all the performers prefer singing in the language the opera was written but prefer Italian. Desblache stated regarding Italian as the language of profane music that "born in Tuscany, the new genre of drama per musica naturally adopted Italian as its international language" (Desblache, 2007: 159) and Italian has been the main language of opera ever since. Although Italian remained the operatic language until the nineteenth century, many composers produced operas in French, German, and English mainly because of the nationalist view, which had taken place in the nineteenth and twentieth centuries especially after the First World War. Therefore, "a trend towards performances of operas in translation into the language of the country where they were performed was established in the nineteenth century" (Desblache, 2007: 161). It can be derived that with the dominant view of nationalism, countries began translating operas into their own language in order to promote their language as also being operatic and melodic. Together with these translations, countries including the Turkish Republic in the twentieth century, tried to create operas in their own languages. However, there were not many operas written in Turkish as stated by the interviewees. Historical musicologist Nicholas Temperley expressed that:

"through much of the Victorian period, both Her Majesty's and Covent Garden [London's two principal opera houses] restricted themselves to opera in Italian for their main seasons. German, French, Russian and even English operas had to be translated before they could be presented" (Temperley, 1992(2001): 524).

It is clearly seen that Italian has been and still continues to be the language of music and most importantly of opera; however, efforts on restricting oneself to Italian and even translating operas in other languages into Italian cannot be regarded as reasonable. Translations should only be done into the language of the target culture and audience and great care must be given while translating the libretti in order to convey the spirit and make the translated libretti singable and performable.

Considering the views of the opera performers on the fifth question, it can be concluded that there is a strong belief among the opera performers that there would not be a benefit in staging the operas in translated versions. Many reasons were given by the opera performers including that the staging of an opera in the original from or translated version was merely a state policy and in the past operas had been staged in translations. Many of the opera performers also suggested that operagoers study the operatic plays beforehand or read the libretto. Yet, according to Maurino, "not just the music but also the language and the verse influence the feeling of the plot so the language itself is an important factor along with the music and singing" (Maurino, 1947: 382-383). Maurino, being against opera translation, put forward that language was also significant in opera as words and notes formed a whole when the composer fit the words to the music and asked: "wouldn't a translation of an opera libretto undo this fusion (fusion being the interaction of the words and the notes) no matter how skilled the translation may be" (Maurino, 1947: 383)? Maurino's view in 1947 can be 
regarded as pure dogma as the notion of surtitling can also be put into the equation. Surtitling was mentioned by all opera performers as being a good method of translating the libretti and reflecting the lines on a screen. However, in also those translations, deficits can be seen while the performer is singing many lines and only one translated line is reflected on the screen. Linda and Michael Hutcheon state regarding surtitles "surtitles do not translate literally what is being sung" (Hutcheon, L. and M., 2010: 875). In surtitling, many variables should be taken into consideration including time, the length of the lines, duration of music, technological opportunities, the audiences' comfort, etc. Hence, the translation of the surtitles may also undo the fusion Maurino talked about and even make it harder to follow the lines, the stage, drama, the mime and the singing at the same time. Thus, although Italian was accepted as the language of the opera a very long time ago, in order to reach a conscious audience, as put forward by the interviewees, conscious translations have to be done and to fulfill conscious translations some criteria have to be followed, which were mentioned in the earlier chapters of the research, including singability, naturalness, sense, rhythm, and rhyme.

Taking the replies given to the sixth question into consideration, opera performers believe that the translations of opera libretti affect the staging of the opera. It can also be said that not just in translations, but also in the original form itself the words have significance in staging the opera. As Linda and Michael Hutcheon point out "words and music were imagined to complement each other, to interact, and to reinforce one another" (Hutcheon, L. and M., 2010: 870). Seeing that the words and music make a meaningful whole in the original libretto, the translations should also have cohesion in themselves in order to have a successful staging. In his book "The Semiotics of Theatre and Drama" Keir Elam distinguishes two different text types for opera; "the dramatic and the performance text" (Elam, 1980[2002] 29-187). In this context, the dramatic text is comprised of the musical and the verbal score. So, the task of the translator turns out to be more than just translating the verbal score, libretto, but also includes the interpretation of the performance texts and creates a performable operatic play. Thus, the translator needs to work with the whole group responsible for the staging of the opera including the director, the conductor, the musicians, the singers, lighting, décor, etc. in order to mediate two dramatic texts, the verbal and the musical, and the performance text. This is also expressed by the interviewees in the research. Translating operas is a multidisciplinary action and many variables including spatial, visual and temporal constraints, language, and performability, should be considered so as to convey the narrative elements of the dramatic texts.

Bearing in mind the answers given to the seventh question, it can be said that language and the choice of words in translation are paramount for the singers. It is understood that words, which have melody and are easy to sing, should be preferred by the translator. Strict obedience to giving the semantic equivalents of the words, in this respect, does not prove to be appropriate for opera translations. If the semantic equivalent is hard to sing, a near synonym or even a totally different word can be chosen instead. However, the spirit of the text and the 
sense should also be conveyed through these words so the chosen words should make the audience believe that those were the exact equivalences of the original words written by the librettist or the composer himself. Semantic relation with the source text deserves to be highranked when talking about translations. According to Johan Franzon, "if the music must be performed as originally scored, as in stage musicals or operas, it must be the translator who modifies the verbal rendering, by approximating more loosely, by paraphrasing or by deleting from and adding to the content of the source lyrics" (Franzon, 2008: 386). This statement of Franzon applies to singable target lyrics, which is mandatory for operas. Deleting or adding words to the source lyrics may meet the expectations of opera singers regarding word choice, as melodic words would be tried to be found by the translator to have a singable version of the source text in the target language.

In view of the answers given to the eighth and last question, it is deduced that not only the original but also the translated opera should address both the ears and the eyes. In the creation of meaning in opera, music, libretto and dramatic performance unite and in harmony put forward an operatic play. This multidisciplinary art form should be regarded as merging many artistic forms including theatre, costume, lighting, décor, musicology and verbal discourse and in order to achieve the best outcome all these aspects should be kept in mind. The translator must work with the people responsible for the staging of the opera and create a translated version of the original that addresses both the ears and the eyes of the audiences. Arthur Jacobs states that "the translator's first responsibility is to the composer; given the music, composed perhaps a hundred or two hundred years ago, he has to match it with a verbal drama which will seem theatrically credible to an audience of today" (Jacobs, 1961:23). This statement of Jacobs can be correlated as such: the translations of operatic texts should come near the melodramatic effect created by the orchestra and the actions of the singer so that the ear can hear exactly what the eye sees. Too literal and faithful translations may not meet this expectation so translations should be done by capturing the spirit of the text and making the eyes see and the eras hear the conveyed spirit.

The reason for conducting these interviews was to reflect the points where the performers were standing in terms of translational action undertaken for opera, singing translated opera libretti, and the acceptance of translated versions of opera libretti. The findings of these interviews have been interpreted and commented on by blending them with the remarks of the scholars.

The main findings of the research can be briefly put forward as such: opera has been the most canonized form of music translation as also set forth by Şebnem Susam-Sarajeva saying “...the pervasiveness of covert and unacknowledged translations in music have generally limited research in this area to overt and canonized translation practices, such as undertaken for the opera" (Susam-Sarajeva, 2008: 189). With the emergence of opera in Italy in the sixteenth century, opera took its stand on the stage of history. Although it took a long time for the other European countries to appreciate and produce operas, the first step they took to internalize 
Italian operas was to translate them into their language and have people watch and accept the art of opera in their native tongues and the Italian style in opera could be observed in the operas written in the original languages of the countries. In the nineteenth century the Romantic Era led to the creation of operas indicating national identities and color. Most importantly in the twentieth century after World War I, national entities could be easily observed in the operas of the European countries. In the Ottoman Empire, however, the first interaction with opera occurred when ambassadors were sent to Europe and watched the operatic plays on stage. It was not until Tanzimat that some steps were taken in the name of translating some operas. Since the music of opera was unfamiliar to the ear of the Ottoman lower classes (at that time the music of the Ottoman Empire was monophonic and opera was a polyphonic musical art form) the élites and the people belonging to the Ottoman Palace only understood, appreciated and watched the operas in the original language. In later years, it is seen that some translated operas were also staged in the Ottoman Empire, as translational activity was important in forming a new literary polysystem that Divan literature lacked. During that time, translational activity was at the center of the literary polysystem, replacing the canonized but insufficient repertoire with repertoire brought by translating the European, especially the French, literary works. But with the start of the political collapse of the Ottoman Empire, although some effort had been made in order to flourish not just opera but also other Western genres, this progress had to be put aside. In the early Republic Period, however, education also played an important role in training opera composers and forming a national opera. Students were sent abroad after the proclamation of the Republic and when they returned, they educated the students in Turkey. Importance given to opera was in the governmental state and at that time famous composers were brought to Turkey in order to continue establishing a polyphonic Turkish music alongside opera. Also in the early Republican Period, translation was in a central position in the literary polysystem. Many works of art including the texts of Greek and Latin philosophers and novels, dramas, and operas of French, German and Italian writers and composers were translated in the Republic Period where translational activity formed the most important state policy. Hasan Ali Yücel stated "Turkey, whose desire was to be a distinguished part of the culture and philosophy of the West, would integrate with this perception and mentality by translating the old and new works of the civilized world into Turkish" (cited in Haciibrahimoğlu: 2008: 57). It can also be derived from Yücel's statement that translational activity had a strong and central position in the literary polysystem of the newly established Turkish Republic. In further years, national operas started to be written and State Opera and Ballet was founded.

However, there have not been many notions or concepts analyzed on how to translate the opera libretti into Turkish. Therefore, wider research had to be done and international criteria and concepts had to be put forward in order to bring this research into light. In an effort to shed light on opera libretti translation, first the text type of opera libretti was searched out and it was found that opera belonged to both the audio-medial and expressive text types theorized 
by Katharina Reiss and developed more deeply by Mary Snell-Hornby. It is understood that in order to translate a hybrid text including elements from both multi-medial and expressive text-types, the connections among music, language, stage directions, drama, and décor should be considered. The performers' acceptance of the translated version of the original libretto also constitutes a vital importance. The prosody of the target language and its realization, timbre, rhyme, rhythm, and melody also have paramount effects on translating the opera libretti. As can also be seen in the answers given by the interviewees, they believe that the wholeness of the original libretto should not be ruined and if the translator is incompetent regarding musical and poetical language then bad translations do happen. Therefore, in order not to have bad translations of operatic plays translators must be competent in music and poetry and work together with the whole production team staging the opera in Turkish. For opera libretti translation to be accepted and greatly performed by the performers the end-purpose of the translations should be understood beforehand. According to the notions of the Skopos theory, the end-purpose of a translated libretto is to be sung. So, in order to create translations that can be sung in Turkish, some criteria have to be followed, which were put forward by Peter Low and analyzed fully in the above sub-headings of this research. Nevertheless, in short it can be said that a sung version of translated libretti should be done with respect to these criteria: singability (referring to the singability of the translated lines), naturalness (referring to the natural language free of archaisms and old usages), sense (referring to conveying the spirit of the libretto and not translating word-by-word but meaning-to meaning), rhyme (referring to strict obedience of the poetic metric feet existing in the original libretto), and rhythm (referring to the importance of the pre-existing music to where the words were fit). In the meantime, as mentioned in above chapters and headings, the location of translated literature and opera libretti translation had to be reviewed in order to explain their importance in the Ottoman and Turkish literary polysystems. It is found that in a literature which needed to re-invent itself and in a country which was established from the ashes of an old empire and strived to adopt Western teachings and values and create its own national identity, translated literature remained in the center and translated works paved the way of forming national novels, dramas and operas that did not exist in the literary polysystem. Although Divan was the canonized literature of its time the secondary position it took in terms of repertoire led to the dominance of translations and translated works. Also in the Republic, with the Westernization process and the need to educate the public of the young Republic with cultural and social norms of the West, translation played a vital role and remained at the center. As the interviewees also stated, opera developed in its full capacity in the Republic Period where Turkish polyphonic music was tried to be formed and this was only realized with the help of translation.

Jacques Derrida pointed out that "a relevant translation would therefore be, quite simply, a 'good' translation, a translation that does what one expects of it, in short, a version that performs its mission, honors its debt..." (Derrida, 2001: 177). In opera libretti translation, as can also be 
seen in the above chapters and interviews of the opera performers, a 'good' or 'relevant' translation is a version that honors its debt of being able to be sung. Not being able to be sung, not caring for the original music and poetical language were what the interviewees complained about and by following the criteria mentioned in Chapter 3 it can be deduced that good translations of opera libretti will be done and perhaps more plays will be put on stage in translated versions and therefore lead children to accept and appreciate operas like the interviewees have always wanted.

Throughout the interview, all of the interviewees mentioned the translational activity called surtitling that is being used in opera houses of today. Although it has been tried to look into surtitling, this research is about staging opera libretti in translated Turkish versions. Therefore, not much interest could be given to the field of surtitling and further research can be carried out in this field.

Opera and therefore music translation have not received much interest from the students and scholars of the field of Translation Studies. Having a multidisciplinary quality and, except for opera, being a non-canonized form of translational activity made not just music but also opera translation of today a challenge. Studying translation, music and opera calls for a multidisciplinary approach and a wide perspective. Dealing with written texts has always been more comfortable but a vast area like music, songs and opera cannot also be put aside. Therefore, in this research functional approaches that offer flexibility were intended to be demonstrated in order to guide translators who undergo such translational activity where they are faced with music and words at the same time and bring new approaches into translation studies both in Turkey and in the world.

Translation, opera and therefore music can be a surprising field for researchers, scholars and translators as its boundaries are still unknown for the world of translation studies. There are still many possibilities to explore and new perspectives to bring to the field. Different genres have different translational norms of their own and with changing technology, cultural understandings and approaches, innovative and striking translational theories and concepts can be put forward by researchers of today, especially in music translation, which is a vast field to explore.

\section{The Identification Tags of the Interviewees}

The first opera performer who was interviewed on the 10th of October, 2013 at 14:22.57 was named Esin TALINLI.

The second opera performer who was interviewed on the 10th of October, 2013 at 14:40.49 was named Funda SALTAŞ.

The third opera performer who was interviewed on the 10th of October, 2013 at 14:55.29 was named Çiğdem ÖNOL.

The fourth opera performer who was interviewed on the 10th of October, 2013 at 15:24.12 was named Selva ERDENER.

The fifth, and last, opera performer who was interviewed on the 10th of October, 2013 at 15:40.04 was named Feryal TÜRKOĞLU. 
Peer-review: Externally peer-reviewed.

Conflict of Interest: The authors have no conflict of interest to declare.

Grant Support: The authors declared that this study has received no financial support.

\section{REFERENCES}

Apter, R., \& Herman, M. (1995). The Worst Translations: Almost Any Opera in English. Translation Review, 48/49 (p.p. 26-32).

Berk, Ö. (2006). Translating the "West": The Position of Translated Western Literature within the Turkish Literary Polysystem. RiLUnE, n. 4 (p.p. 1-18).

Creswell, J. W. (2003). Research Design: Qualitative, Quantitative and Mixed Methods Approaches. ${ }^{\text {nd }}$ Ed. Sage Publications.

Derrida, J. (2001). What is a "Relevant" Translation. Critical Inquiry. vol. 27 n. 2 (Winter 2001). trans. by Lawrence Venuti. pub. by The University of Chicago Press. (p.p. 174-200).

Desblache, L. (2007). Music to my ears, but words to my eyes? Text, opera and their audiences. Linguistica Antwerpiensa. n. 6 (p.p. 155-170).

Elam, K. (1980[2002]). The Semiotics of Theatre and Drama. London: Routledge.

Franzon, J. (2008). Choices in Song Translation: Singability in Print, Subtitles and Sung Performance. The Translator: Studies in Intercultural Communication. vol. 14 n. 2 Manchester: St. Jerome Publishing. (p.p. 373-399).

Haciibrahimoğlu, I. Ç. (2008). Translation Studies as the Touchstone of the Republic Period. International Review of Turkology. vol. 1 n. 2 (p.p. 55-65).

Hutcheon L., \& Hutcheon M. (2010). Prima la musica, poi le parole? Operatic Challenges to Word-Music Relations. University of Toronto Quarterly. vol. 79 n. 3 Toronto: University of Toronto Press (p.p. 869-880).

Jacobs, A. (1961). On Translating Opera. The Musical Times. vol. 102 n. 1415 Musical Times Publications Ltd. (Jan. 1961) (p.p. 23-25).

Komşuoğlu, A., \& Turan, N. S. (2007). From Empire to the Republic: the western music tradition and the perception of opera. International Journal of Turcologia. vol. 2 n. 3 (p.p. 5-29).

Low, P. (2003). Singable Translations of Songs. Perspectives: Studies in Translatology. 11:2 Routledge (p.p. 87-103).

Low, P. (2005). The Pentathlon Approach to Translating Songs. Song and Significance: Virtues and Vices of Vocal Translation. ed. Dinda L. Gorlée. Amsterdam: NLD Editions Rodopi (p.p. 185-213).

Maurino, F. D. (1947). The Opera and Its Language. Hispania. vol. 30 N.3 (Aug. 1947) pub. by American Association of Teachers of Spansih and Portuguese. (p.p. 382-384).

Orero, P., \& Matamala, A. (2007). Accessible Opera: Overcoming Linguistic and Sensorial Barriers. Perspectives: Studies in Translatology. 15:4 Taylor and Francis: Routledge (p.p. 262-277).

Snell-Hornby, M. (1997). Written to be Spoken: The Audio-Medial Text in Translation. Text Typology and Translation. ed. Anna Trosberg. John Benjamins Publishing. (p.p. 277-288).

Susam-Sarajeva, S. (2008). Translation and Music: Changing Perspectives, Frameworks and Significance. The Translator. vol. 14 n. 2 Manchester: St. Jerome Publishing (p.p. 187-200).

Şahin Soy, Ö., \& Şenol Özdemir, M. (2015). General Review of Opera Libretti Translation into Turkish. Çeviribilim Özel Bölümü II, Littera (Cilt 35) (pp. 197-207). 
The Historical Journey of Opera Translation in Turkey and its Perception by Contemporary Turkish Opera...

Temperley, N. (1992[2001]). Great Britain. The New Grove Dictionary of Opera. ed. Stanley Sadie London: Macmillan Press.

Devlet Opera ve Balesi Genel Müdürlügü Stratejik Planı (2011-2015). http://www.sp.gov.tr/upload/ xSPStratejikPlan/files/YBS7M+DevletOperaveBalesiSP1115.pdf downloaded in November 24 ${ }^{\text {th }}, 2013$. 